GRASAS Y ACEITES 71 (1)

January-March 2020, e343

ISSN-L: 0017-3495

https://doi.org/10.3989/gya.1170182

\title{
Effects of the drying process on the fatty acid content, phenolic profile, tocopherols and antioxidant activity of baru almonds (Dipteryx alata Vog.)
}

\author{
M.L.L. Campidelli ${ }^{\mathrm{a}, \bowtie}$, J.D.S. Carneiro ${ }^{\mathrm{a}}$, E.C. Souza ${ }^{\mathrm{a}}$, M.L. Magalhães ${ }^{\mathrm{a}}$, \\ E.E.C. Nunes ${ }^{\mathrm{a}}$, P.B. Faria ${ }^{\mathrm{a}}$, M. Franco ${ }^{\mathrm{b}}$ and E.V.B. Vilas Boas ${ }^{\mathrm{a}}$ \\ ${ }^{a}$ Federal University of Lavras - UFLA, Lavras, Minas Gerais, Brazil. \\ ${ }^{b}$ State University of Santa Cruz - UESC, Ilhéus, Bahia, Brazil. \\ Corresponding author: marina.lamounier@yahoo.com.br
}

Submitted: 16 November 2018; Accepted: 14 March 2019; Published online: 13 January 2020

\begin{abstract}
SUMMARY: This study carried out a chromatographic and spectrophotometric characterization of the bioactive compounds, antioxidants, phenolics, tocopherols, sterols and fatty acids of baru almonds "in natura" and submitted to drying processes. It was determined that baru "in natura" almonds presented high levels of phenolic compounds, vitamin $\mathrm{C}$, antioxidants, phenolics, sterols, total monounsaturated fatty acids and low thrombogenic, and atherogenic indexes. During the process of drying it at $65^{\circ} \mathrm{C}$ for 30 minutes, a decrease was noted in the levels of caffeic acid, chlorogenic acid, anthocyanins, $p$-coumaric acid, ferulic acid, $o$-coumaric acid, quercetin, and polyunsaturated fatty acids. The same condition resulted in an increase in the levels of gallic acid, rutin, catechin, trans-cinnamic acid, vanillin, m-coumaric acid, tocopherols, monounsaturated fatty acids and antioxidant activity (ORAC and DPPH). When submitted to a temperature of $105^{\circ} \mathrm{C}$ for 30 minutes the same behavior was seen with a reduction in the vitamin $\mathrm{C}$ and ORAC contents and increased presence of flavonoids.
\end{abstract}

KEYWORDS: Antioxidant activity; Bioactive compounds; Brazilian Cerrado; High-Performance Liquid Chromatography; Oilseeds

RESUMEN: Efectos del proceso de secado sobre la composición en ácidos grasos, perfil fenólico, tocoferoles y actividad antioxidante de almendras barú (Dipteryx alata Vog.). Este estudio realizó una caracterización cromatográfica y espectrofotométrica de la presencia de compuestos bioactivos, antioxidantes, fenólicos, tocoferoles, esteroles y ácidos grasos en almendras del tipo baru "in natura" y sometidos a procesos de secado. Se detectó, en la almendra de baru "in natura", altos contenidos de compuestos fenólicos, vitamina C, antioxidantes fenólicos, esteroles, ácidos grasos monoinsaturados totales y bajos índices de trombogénicos y aterogénicos. Durante el proceso de secado a $65^{\circ} \mathrm{C}$ durante 30 minutos, se observó una disminución en los niveles de ácido cafeíco, ácido clorogénico, antocianinas, ácido $p$-cumárico, ácido ferúlico, ácido o-cumárico, quercetina y ácidos grasos poliinsaturados. De la misma manera se observó un aumento en los niveles de ácido gálico, rutina, catequina, ácido trans-cinámico, vanilina, ácido $m$-cumárico, tocoferoles, ácidos grasos monoinsaturados y actividad antioxidante (ORAC y DPPH). Cuando se sometió a una temperatura de $105^{\circ} \mathrm{C}$ durante 30 minutos, presentó el mismo comportamiento, sin embargo, influyó en la reducción del contenido de vitamina C y ORAC y aumentó la presencia de flavonoides.

PALABRAS CLAVE: Actividad antioxidante; Cerrado Brasileño; Compuestos bioactivos; Cromatografía líquida de alta resolución; Semillas oleaginosas

ORCID ID: Campidelli MLL https://orcid.org/0000-0002-0127-2943, Carneiro JDS, https://orcid.org/0000-0003-40605891, Souza EC https://orcid.org/0000-0002-3369-4892, Magalhães ML https://orcid.org/0000-0001-8006-2487, Nunes EEC https://orcid.org/0000-0002-1124-8066, Faria PB https://orcid.org/0000-0002-2890-5472, Franco M https://orcid. org/0000-0002-7827-789X, Vilas Boas EVB https://orcid.org/0000-0002-0252-695X

Citation/Cómo citar este artículo: Campidelli MLL, Carneiro JDS, Souza EC, Magalhães ML, Nunes EEC, Faria PB, Franco M, Vilas Boas EVB. 2020. Effects of the drying process on the fatty acids, phenolic profile, tocopherols and antioxidant activity of baru almonds (Dipteryx alata Vog.) Grasas Aceites 71 (1), e343. https://doi.org/10.3989/ gya.1170182

Copyright: (C2020 CSIC. This is an open-access article distributed under the terms of the Creative Commons Attribution 4.0 International (CC BY 4.0) License. 


\section{INTRODUCTION}

Drying is one of the oldest processes used by man for preserving food. Due to reduced water activity, there is a minimization of microbial growth which results in an increased shelf-life of raw materials. It can facilitate and reduce the costs of packaging, transport and storage, in addition to bringing improvements in sensory aspects (especially when it comes to oleaginous seeds since the majority, when in natura, have a bitter and astringent taste due to the presence of tannins), inhibiting anti nutritional factors and providing raw material throughout the year (Igual et al., 2012).

Despite the benefits, it is estimated that drying can contribute to a reduction in the functional activity of food, because the vast majority of bioactive compounds exhibit heat-sensitive behavior (Lemos et al., 2012; Lemos et al., 2016). There is a high incidence of producers that improperly employ this technique in their raw materials. As a result, there is a distribution of products with compromised functional activity, and oilseeds are the most affected, as these employ this method of conservation.

In order to maintain the nutritional quality of food, the verification of bioactive compound changes during the drying process must be monitored. Recent research has linked a daily consumption of oilseeds with reduced incidence of chronic non-communicable diseases due to the presence of biologically active substances (Liu et al., 2019).

Despite the limited amount of information about the baru almond (Dipteryx alata Vog.), it stands out for its superior nutritional composition (Fraguas et al., 2014; Lemos et al., 2016). It contains high levels of lipids, proteins, amino acids, and minerals (such as calcium, iron, magnesium, potassium and zinc) and dietary fiber (Fraguas et al., 2014). Besides being found in regions with high sun exposure, the plant's defense system promotes protection from the sun through the biosynthesis of secondary compounds that present bioactive characteristics. These substances have the ability to minimize the action of free radicals through the interception of active oxygen (responsible for oxidative damage in cell membranes and DNA), and they can assist in the prevention of chronic non-communicable diseases (Lemos et al., 2012).

In spite of the aforementioned benefits, research is limited on the specific compounds that exhibit desirable characteristics for minimizing chronic non-communicable diseases, such as fatty acids and phenolics and tocopherols. Therefore, with the aim of obtaining complete and efficient use of baru almonds to meet their new functional properties, detailed research on the presence of different bioactive compounds such as phenolic metabolites, fatty acids, and tocopherols, among others is necessary.
In addition, it is necessary to monitor the effectiveness of the two drying processes $\left(65\right.$ and $105^{\circ} \mathrm{C}$ for 30 minutes) which are the most often used by the producers of this food, because the vast majority reach the consumer in this condition.

Therefore, in order to extend the knowledge about the functional potential of compounds and investigate the possible changes resulting from processing, the present study aimed to carry out a chromatographic and spectrophotometric characterization regarding the presence of bioactive compounds, antioxidants, sterols and phenolic profiles, tocopherols and fatty acids in baru almonds "in natura" and subjected to the drying process.

\section{MATERIALS AND METHODS}

\subsection{Reagents, materials and experimental design}

All chemicals, reagents and solvents used were of analytical grade or HPLC and obtained from Sigma-Aldrich (St. Louis, MO, USA). Deionized water (> $18 \mathrm{M} \Omega . \mathrm{cm})$ was obtained from a Milli-Q system (Millipore, Brussels, Belgium).

The buru almonds were obtained from the Cerrado Biome region, located in the city of Barra do Garças-MT, during the harvest season (between August and September 2016). The baru almond has the following centesimal composition $(\mathrm{g} / 100 \mathrm{~g}): 6.63$ moisture, 22.96 protein, 31.73 lipid, 14.44 dietary fiber and it wieghs 1.55 grams.

For this work, the completely randomized experimental design was used with three replications. Three treatments were evaluated: baru almonds "in natura" (T1 - which was the control for the drying experiment), baru almonds submitted to drying at $65^{\circ} \mathrm{C}$ for $30 \mathrm{~min}(\mathrm{~T} 2)$ and baru almonds subjected to drying at $105^{\circ} \mathrm{C}$ for $30 \mathrm{~min}$ (T3). The temperatures were chosen because they are the most commonly used by the producers of these oleaginous plants. In addition, it is known that the roasting process compromises part of the nutritional and bioactive value of the food, and therefore to use lower temperatures which are effective in drying the baru almond preserve its nutrients can become a new form of use and consumption for this food.

\subsection{Drying process}

The drying of the baru almonds was carried out in a forced air circulation oven (Marconi, MA0351, Piracicaba, Brazil). They were then ground (20 mesh - in experimental mill, Viti Molinos, VG 2000i, Itajaí, Brazil), packed in transparent polyethylene containers and stored at $25^{\circ} \mathrm{C}$ (oven model Eletrolab, EL202). During the drying processes, the time and temperature were chosen because they are yet to be investigated. The moisture contents of the almonds were determined after the drying process (AOAC, 
1990 ) and the averages were $6.63,5.10$ and $2.64 \mathrm{~g} \cdot 100$ $\mathrm{g}^{-1}$ respectively for $\mathrm{T} 1 \mathrm{~T} 2$ and $\mathrm{T} 3$. All the results of the analytical determinations described below (including moisture) were expressed on a wet basis.

\subsection{Determination of bioactive compounds}

The contents of total phenolic compounds, anthocyanins, flavonoids, tannins and vitamin C were evaluated. The hydroalcoholic extract was prepared according to the methodology adapted from Milardovic et al., (2006).

Total phenolics were determined by the FolinCiocalteu reagent method, using gallic acid as the standard for the calibration curve. The absorbance was measured at $765 \mathrm{~nm}$ in a spectrophotometer (UV-Visible 50 Probe-Cary) and the results were expressed in mg of gallic acid equivalent (GAE) 100 $\mathrm{g}^{-1}$ (Lemos, 2012).

The total phenolic compounds were also evaluated by the use of diazonium salt Fast Blue BB, using standard gallic acid for the calibration curve. The absorbance was measured at $420 \mathrm{~nm}$ in a spectrophotometer (UV-Visible 50 Probe-Cary) and the results were expressed in milligrams gallic acid equivalent (GAE) per $100 \mathrm{~g}^{-1}$ (Palombini et al., 2016).

Monomeric anthocyanins were determined by the differential $\mathrm{pH}$ method described by Giusti and Wrolstad (2001), using a spectrophotometer (UV-Visible 50 Probe-Cary) for absorbance measurements of samples (510 and $700 \mathrm{~nm})$ and the results were calculated as malvidin-3,5-diglucoside.

Flavonoids were determined following the methodology described by Fraguas et al., (2014). The reading was held at $415 \mathrm{~nm}$ spectrophotometer (UV-Visible 50 Probe-Cary) using a $\%$ solution of aluminum chloride in methanol. The total flavonoid values were expressed as equivalents of catechin.

Tannins were measured by the colorimetric method according to the Association of Official Analytical Chemists (AOAC, 1990). The method was based on the intensity of the blue color produced in reducing the Folin-Denis reagent for phenols, and was then measured in the spectrophotometer (UV-Visible 50 Probe-Cary) to $760 \mathrm{~nm}$ expressed as equivalents of catechin.

Vitamin $\mathrm{C}$ was evaluated by the colorimetric method using 2,4-dinitrophenylhydrazine and the results were read on a spectrophotometer (UV-Visible 50 Probe-Cary) to $520 \mathrm{~nm}$ and expressed in equivalents of ascorbic acid (Milardovic et al., 2006).

\subsection{Individual identification of phenolic compounds by HPLC-DAD}

The individual identification of phenolic compounds was made following the methodology described by Ramaiya et al.,(2013). The quantification and identification of these phenols compounds were performed in a liquid chromatography (HPLC-DAD/ UV-Vis) model Shimadzu (Shimadzu Corp., Kyoto, Japan) equipped with a gradient pump (2487 Serie), a valve injector with a loop of $50 \mu \mathrm{L}$, a degasser (Waters 200 Series) and an integrator-plotter with software (Total Chrom, Waters). Phenolic compounds were separated in a C18 reversed-phase column $(150 \mathrm{~mm} \times 4.6 \mathrm{~mm}$ I.D., $5 \mu \mathrm{M})$, (Phenomenex, CA, USA) with a C18 $(20 \mathrm{~mm} \times 4.6 \mathrm{~mm}$ I.D. $)$ pre-column cartridge. The mobile phase consisted of $2 \%(\mathrm{v} / \mathrm{v})$ acetic acid in deionized water (mobile Phase A) and 70:28:2 (v/v) methanol/water/acetic acid (mobile phase B), and phenolics were detected at $280 \mathrm{~nm}$. Phenolic compounds were identified by comparison of retention times with standards (gallic acid, catechin, chlorogenic acid, caffeic acid, vanillin, $p$-coumaric acid, ferulic acid, $m$-coumaric acid, $o$-coumaric acid, trans-cinnamic acid, quercetin and rutin). The results were expressed as $\mathrm{mg}$ of phenolic compound in $100 \mathrm{~g}^{-1}$ of fresh weight.

\subsection{Screening of antioxidant activity}

Test for elimination of free radicals (DPPH $\bullet$ ). The antioxidant activity was evaluated by the $\mathrm{DPPH} \cdot$ scavenging ability of the antioxidant activity. Absorbance was measured using UV-Visible spectrophotometer (50 Probe-Cary) at $517 \mathrm{~nm}$ expressed as $\%$ of free radical sequestration (Milardovic et al., 1943).

Antioxidant activity via $\beta$-carotene/linoleic acid system. Antioxidant activity determination by $\beta$-carotene/linoleic acid system was conducted according to the methodology described by Miller (1971) and absorbance was measured at $470 \mathrm{~nm}$ with a spectrophotometer (UV-Visible 50 ProbeCary). The results were expressed as percentage of inhibition of $\beta$-carotene oxidation.

Oxygen Radical Antioxidant Capacity (ORAC) assay. The ORAC method used, with fluorescein (FL) as the "fluorescent probe", was applied as described by Aazza et al., (2011).

\subsection{Determination of total sterols, tocopherols and fatty acids}

The levels of total sterols, tocopherols and fatty acids present in baru almonds were determined. To carry out these analyses, it was necessary to extract the oil present in the baru almond.

\subsubsection{Process of baru almond oil extraction}

To extract the oil from the almonds, an Extractor Oster (yoda model $60 \mathrm{~Hz}$ ) was used with the following specifications: rated power-400W, Turbo-electric heating mode. Subsequently, the oil was transferred to amber jars and kept under refrigeration $\left(4{ }^{\circ} \mathrm{C}\right)$. 
This method was chosen because it is a method that extracts lipids in the cold.

Total sterols. For the reading of the samples $0.8 \mathrm{~mL}$ of Lieberman-Burchard, reagent was added to $0.1 \mathrm{~g}$ of the sample and $3.1 \mathrm{~mL}^{-1}$ of chloroform, and left to stand for $12 \mathrm{~min}$. The solution was ready in the $625 \mathrm{~nm}$ spectrophotometer (UV-Visible 50 Probe-Cary), using chloroform as white (Kenny, 1952).

Identification of tocopherols by HPLC-DAD. For the determination of tocopherols $(\alpha$ and $\gamma), 0.08 \mathrm{~g}$ of the obtained oil was dissolved in $4.0 \mathrm{~mL}$ of 2-propanol. The analysis was performed by liquid chromatography (HPLC-DAD/UV-Vis) model Shimadzu (Shimadzu Corp., Kyoto, Japan) equipped with a gradient pump (2487 Series), a valve injector with a loop of $50 \mu \mathrm{L}$, a degasser (Waters 200 Series) and an integrator-plotter with software (Total Chrom, Waters). Vitamin E was separated on a C18 reversed-phase column $(150 \mathrm{~mm} \times 4.6 \mathrm{~mm}$ I.D., $5 \mu \mathrm{M})$, (Phenomenex, CA, USA) with a C18 (20 mm $\times 4.6 \mathrm{~mm}$ I.D.) pre-column cartridge. The mobile phase consisted of a mixture of methanol $(96 \%)$ and water $(4 \%)$ using the isocratic solvent and system with a flow rate of $1.0 \mathrm{~mL}$ min. Detection was made at $292 \mathrm{~nm}$. The quantification of $\alpha$ and $\gamma$ tocopherol was performed using the external standard method. The results were expressed in $\mathrm{mg}$ of tocopherol $100 \mathrm{~g}^{-1}$ (Freitas et al., 2008).

Profile of fatty acids by CG-FID. For the analysis of fatty acid profile, the lipids were extracted according to the procedures described by Folch et al., (1957). The analysis was performed by gas chromatography on a Shimatzu CG 2010 chromatograph (Agilent Technologies Inc., Palo Alto, CA, USA), equipped with a flame ionization detector, split injection at the rate of 1:50 and capillary column SPTM-2560 Supelco, $100 \mathrm{~m} \times 0.25 \mathrm{~mm}$ $\times 0.20 \mu \mathrm{m}$ (Supelco Inc., Bellefonte, PA, USA). The initial temperature of the column was $140{ }^{\circ} \mathrm{C}$, maintained for $5 \mathrm{~min}$, changing to $240{ }^{\circ} \mathrm{C}$ with increments of $4{ }^{\circ} \mathrm{C}$, maintained for $30 \mathrm{~min}$ for a total of $60 \mathrm{~min}$. The injector and detector were kept at the temperature of $260{ }^{\circ} \mathrm{C}$ and helium was used as the carrier. The identified fatty acids were compared to the retention times presented by the chromatographic pattern SupelcoTM37 FAME Mix (Supelco Inc., Bellefonte, PA, USA) and expressed in percentage $(\%)$ of the total fatty acids. Later they were grouped according to saturated fatty acids (SFA), monounsaturated fatty acids (MUFAs) and polyunsaturated fatty acids (PUFAs). The atherogenic index (AI) and thrombogenic index (TI) were determined in accordance with those specified by Ulbricht and Southgate (1991), as in equations 1 and 2 :

$$
\begin{gathered}
\text { AI: }[(\mathrm{C} 12: 0+(4 \times \mathrm{C} 14: 0)+\mathrm{C} 16: 0)] / \\
(\Sigma \mathrm{MUFAs}+\Sigma \Omega 6+\Sigma \Omega 3)
\end{gathered}
$$

$$
\begin{gathered}
\mathrm{TI}:(\mathrm{C} 14: 0+\mathrm{C} 16: 0+\mathrm{C} 18: 0) /[(0.5 \times \Sigma \mathrm{MUFAs})+ \\
(0.5 \times \Sigma \Omega 6)+(3 \times \Sigma \Omega 3)+(\Sigma \Omega 3 / \Sigma \Omega-6)]
\end{gathered}
$$

The ratio of fatty acids hypocholesterolemic and hypercholesterolemic $(\mathrm{h} / \mathrm{H})$ was calculated according to the formula described by Santos-Silva (2002) and shown in equation 3 :

$$
\begin{gathered}
\text { h/H:(C18:1+C18:2+C20:4+C18:3+ } \\
\text { C20:5+C22:5+C22:6)/(C14:0+C16:0) }
\end{gathered}
$$

\subsection{Statistical Analysis}

The results were submitted to analysis of variance (ANOVA) and test for comparison of averages (5\% probability of error according to the Tukey test). Statistical calculations were performed using the program $\mathrm{R}^{\circledR}$ version 5.0. The differences were considered significant when $p<0.05$.

\section{RESULTS AND DISCUSSION}

\subsection{Determination of bioactive compounds present in baru almonds}

The results of the determinations of total phenolics, monomeric anthocyanins, flavonoids, tannins and vitamin $\mathrm{C}$ of baru almonds are displayed in Table 1.

It was observed that the drying processes did not alter the total phenolic or tannins because these compounds remained unchanged $(p>0.05)$, thus showing the thermal stability to these temperatures. When applied to the process of $65^{\circ} \mathrm{C}$ for $30 \mathrm{~min}$ (T2), a significant reduction $(p<0.05)$ was detected only in the presence of monomeric anthocyanins, which proves these molecules are sensitive to such a drying process. When using $105{ }^{\circ} \mathrm{C}$ for $30 \mathrm{~min}$ (T3) they were reduced $(p<0.05)$ in addition to the anthocyanins and vitamin $\mathrm{C}$, although the level of flavonoids increased $(p<0.05)$.

In reference to the means obtained from the determination of phenolic compounds, it the predominance of these substances in baru almonds was demonstrated, which in turn, exceeded the values reported for other nuts (with an averages between 32 and $420 \mathrm{mg} \cdot 100 \mathrm{~g}^{-1}$ for macadamias, cashews, walnuts, hazelnuts and peanuts) (Kornsteiner et al., 2006). The process of drying was found not to influence this content and this behavior can be associated with the absence of oxidative reactions by reactive oxygen species. Discrepant behavior was found by Lin et al., (2016), who studied the effect of drying on almonds $\left(150{ }^{\circ} \mathrm{C}\right.$ for $\left.20 \mathrm{~min}\right)$ and found that the phenolic compounds were reduced. Pasqualone et al., (2018), when studying the drying process of almond by-products, also found a significant reduction in the presence of phenolic compounds in these foods. 
TABLE 1. Average values of total phenolics (measured by Folin Ciocalteau methods and Fast Blue BB), monomeric anthocyanins, total flavonoids, tannins, vitamin C, ORAC, DPPH and $\beta$-carotene/linoleic acid present in baru almonds submitted to different drying processes ${ }^{1}$

\begin{tabular}{|c|c|c|c|c|}
\hline \multirow[b]{2}{*}{ Analytical Determinations } & \multicolumn{4}{|c|}{ Treatments $^{2}$} \\
\hline & T1 & $\mathbf{T 2}$ & T3 & $\mathbf{P}$ \\
\hline 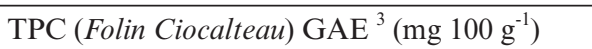 & $1254.12 \pm 39.71$ & $1175.23 \pm 35.15$ & $1306.34 \pm 33.18$ & 0.6229 \\
\hline TPC (Fast Blue BB) GAE $^{3}\left(\mathrm{mg} 100 \mathrm{~g}^{-1}\right)$ & $179.14 \pm 1.54$ & $167.85 \pm 1.42$ & $186.56 \pm 1.26$ & 0.5698 \\
\hline Monomeric Anthocyanins (mg $100 \mathrm{~g}^{-1}$ ) & $0.38 \pm 0.02^{\mathrm{a}}$ & $0.32 \pm 0.01^{\mathrm{b}}$ & $0.25 \pm 0.02^{\mathrm{c}}$ & 0.0006 \\
\hline Total Flavonoids $\mathrm{QE}^{4}\left(\mathrm{mg} 100 \mathrm{~g}^{-1}\right)$ & $9.17 \pm 0.45^{\mathrm{b}}$ & $8.01 \pm 1.46^{\mathrm{b}}$ & $15.73 \pm 0.45^{\mathrm{a}}$ & 0.0001 \\
\hline Tannins $\mathrm{CE}^{5}\left(\mathrm{~g}_{\left.100 \mathrm{~g}^{-1}\right)}\right.$ & $1.51 \pm 0.87$ & $1.62 \pm 0.65$ & $1.67 \pm 0.89$ & 0.1567 \\
\hline Vitamin $\mathrm{C}^{6}\left(\mathrm{mg} 100 \mathrm{~g}^{-1}\right)$ & $39.14 \pm 0.43^{\mathrm{a}}$ & $37.85 \pm 0.79^{\mathrm{a}}$ & $35.23 \pm 0.31^{\mathrm{b}}$ & 0.0004 \\
\hline ORAC $^{7}\left(\mathrm{uM} \mathrm{g}^{-1}\right)$ & $4.06 \pm 0.76^{\mathrm{a}}$ & $3.43 \pm 0.98^{\mathrm{b}}$ & $2.96 \pm 0.45^{\mathrm{c}}$ & 0.0029 \\
\hline $\mathrm{DPPH} \bullet(\% \mathrm{SRL})$ & $69.02 \pm 2.86^{\mathrm{b}}$ & $79.68 \pm 3.78^{\mathrm{b}}$ & $84.38 \pm 3.98^{\mathrm{a}}$ & 0.0056 \\
\hline$\beta$-carotene/linoleic acid system ( $\%$ protection) & $91.72 \pm 3.35$ & $89.94 \pm 10.52$ & $86.10 \pm 1.42$ & 0.5738 \\
\hline
\end{tabular}

${ }^{1}$ Mean values \pm standard deviation (in quadruple, $\mathrm{n}=4$ ). Values followed by different letters in the same line show differences by Tukey's test at $95 \%$ significance ( $\mathrm{p}<0.05$ ); ${ }^{2}$ Treatments: T1 (Almond "in natura"), T2 (Almond subjected to drying at $65{ }^{\circ} \mathrm{C}$ for 30 minutes) and T3 (Almond subjected to drying at $105{ }^{\circ} \mathrm{C}$ for 30 minutes); ${ }^{3} \mathrm{TPC}$ : Total Phenolic Compounds; GAE: Gallic acid equivalent; ${ }^{4}$ Equivalent of rutin; ${ }^{5}$ Equivalent of catechin; ${ }^{6}$ Expressed in $\mathrm{mg}$ of ascorbic acid; ${ }^{7}$ Equivalent of trolox; $p$ : $p$-value.

On the other hand, the use of the Fast Blue BB method provided a reduction in the detection of these phenolic substances, demonstrating a difference between the two processes. This evidence is attributed to the fact that this procedure is specific and unique to the quantification of phenols, for pure reagents which are not mixed with other compounds such as proteins, sugars or ascorbic acid reducers (as occurs in the Folin Ciocalteau's method) (Naczk and Shahidi, 2004). It was noted that this methodology presented greater precision for determining these substances.

Concerning the quantification of monomeric anthocyanins in baru almonds, a considerable reduction $(p<0.05)$ was observed $(15.78 \%$ and $34.21 \%$, respectively in T2 and T3). It was observed that the higher the temperature of the drying process, the greater the degradation of these substances. A negative effect of the temperature/oxygen interaction was evidenced, which was detrimental to the maintenance of these molecules.

Higher flavonoid contents were found in treatment T3 when compared to $\mathrm{T} 1$ and $\mathrm{T} 2$, indicating that the process of drying at $105^{\circ} \mathrm{C}$ for $30 \mathrm{~min}$ increased $(p<0.05)$ the presence of these molecules by $72 \%$. The increase in bioactive compounds, such as flavonoids, may be related not only to the degradation of polymeric polyphenols and flavonoid glycosylated hydrolysis (Lemos et al., 2012) but also to the Maillard products reaction (Liu, Kitts, 2011). In addition, the intracellular water evaporation could have changed the lignocellulosic structure, in addition to promoting the denaturation of proteins, resulting in an increased availability of active compounds in the array (Lemos et al., 2012). Similar behavior was found by Lin et al., (2016), who concluded that the roasting process $\left(200^{\circ} \mathrm{C}\right.$ for $20 \mathrm{~min}$ ) contributed to the increase of $124 \%$ in the content of flavonoids in almonds.

With respect to tannins, a considerable presence was observed in baru almonds and the drying processes were found not to promote a significant reduction $(p>0.05)$ thereof. The abundant consumption of this substance should be controlled because the exploitation of minerals and proteins causes antinutritional effects. However, as the consumption of "in natura" baru almonds is not a common practice, mostly due to its sensory characteristics in this condition (bitter and astringent), the application of heat becomes an important feature that aims to improve the sensory aspects and inactivate the antinutritional substances. Recent researches has indicated that these substances present anti mutagenic potential, which, in turn, are related to their antioxidant potential, and are effective in protection from oxidative damage (Macáková et al., 2014).

The concentration of vitamin $\mathrm{C}$ was fond to decrease $(p<0.05)$ by $9.98 \%$ due to the drying process at $105^{\circ} \mathrm{C}$ for $30 \mathrm{~min}$ in $\mathrm{T} 3$, which can be assigned to a likely oxidation of this vitamin, which by its biologically active nature, is unstable and reversibly oxidized to Ldehidroascórbic acid. Even with this, it was found that the treatments corresponded to a high content of vitamins. According to the Dietary Guidelines for Americans (McGuire, 2011), the recommendation of daily vitamin $\mathrm{C}$ intake is $75 \mathrm{mg}$ for women and $90 \mathrm{mg}$ for men over 30 years old. These levels are based on their physiological functions and antioxidants needed to benefit the physiological organism. In this regard, when $100 \mathrm{~g}$ of baru almonds are consumed, treatments T1, T2 and T3 may represent 52.2, 46.9 and $50.5 \%$, respectively, of the recommendation for women, and 41.4, 43.5 and $39.2 \%$ for men. It is found that this almond is a food 
with high levels of this nutrient. It is important to note that Fatin and Azrina (2017) have found lower results for vitamin $C$ in fresh lime $\left(27.78 \mathrm{mg} \cdot 100 \mathrm{~g}^{-1}\right)$, which is one of the referenced foods for this vitamin. Therefore, the consumption of baru almonds may be beneficial in the case of possible vitamin deficiencies.

\subsection{Screening for antioxidant activity}

Test of elimination of free radicals (DPPH•). The results obtained for the total antioxidant levels analyzed by the DPPH method were 69.02, 79.68 and $84.38 \%$ free radical scavenging capacity for $\mathrm{T} 1$, $\mathrm{T} 2$ and T3, respectively (Table 1 ). The drying process at $105{ }^{\circ} \mathrm{C}$ for 30 min promoted a significant reduction $(p<0.05)$ in T3, decreasing by $36.05 \%$ the $\mathrm{DPPH} \bullet$ radical scavenging capacity in comparison with baru almonds "in natura". However, almond T2 remained stable when compared to T1 (control), therefore, it is reasonable to conclude that the drying process held at $65^{\circ} \mathrm{C}$ for $30 \mathrm{~min}$ did not reduce the presence of antioxidants in almonds. It was found that more intense heat treatments could be responsible for the loss in antioxidants. Lemos et al., (2012), explained that during heating, part of the moisture was lost through evaporation and the Maillard reaction increased the antioxidant capacity of the almonds. Higher values for free radical scavenging capacity indicate a lower antioxidant activity. Some compounds do not react against the DPPH $\bullet$ free radical because they are lipophilic and, therefore, it is necessary to apply different methodologies that seek to characterize such components.

Antioxidant activity via $\beta$-carotene/linoleic acid system. The total antioxidant activity was also measured by the $\beta$-carotene/linoleic acid system and the average value obtained among treatments was $89.24 \%$ protection without any statistical differences $(p>0.05)$ (Table 1). These results indicated that baru almonds presented high levels of these components and heat-resistant behavior. These data present promising results because oxidative processes can be avoided through the use of antioxidants with prevention or decrease in triggering oxidative reactions. Moreover, this method is suitable for the investigation of lipophilic antioxidants and fits the constitution of baru almonds especially due to their high lipid content.

Oxygen radical activity capacity (ORAC) assay. In the ORAC method it was observed that baru almond "in natura" showed significantly $(p>0.05)$ more antioxidant capacity when compared to the other treatments (Table 1). As they are heat-sensitive substances, the drying processes have contributed to the reduction in this attribute. As this essay is based on a hydrogen atom transfer reaction using a free radical source which is predominant in human biology (peroxyl radical), the ORAC test is relevant to express the antioxidant capacity of a given substance under in vivo conditions.

\subsection{Individual identification of phenolic compounds by HPLC-DAD}

A total of twelve phenolic compounds were detected in the three treatments, and the results associated with the identification and quantification of these molecules are shown in Table 2.

Among the phenols identified by high-performance liquid chromatography, gallic acid was the main phenolic compound in baru almonds. It should be noted that the high contents of these substances in food, more specifically in almonds, are desirable because they provide health benefits. Gallic acid, which has a strong free radical capacity, is effective in preventing disease, and research indicates that it is able to induce apoptosis and cytotoxic and antiproliferative effects among different strains of tumor cells (Guimarães et al., 2007). As the drying process increased these substances (which was an increase of 1.07 times), we can infer that the benefits to be achieved through the ingestion of these molecules can be enhanced. Lin et al., (2016) have also observed a significant increase in the presence of gallic acid in almonds dried at $150{ }^{\circ} \mathrm{C}$ for $30 \mathrm{~min}$. However, this increase was 13 times greater (when compared to raw almonds) and the end content of this substance was $52 \mathrm{mg} \cdot 100 \mathrm{~g}^{-1}$.

It was found that other components, such as catechin, vanillin, trans-cinnamic acid, $m$-coumaric acid and rutin, were increased $(p<0.05)$ with the drying process (when compared to the "in natura" treatment), and this increase was 1.22, 1.34, 1.19, 1.17 and $1.03 \%$, respectively. One possible explanation for this increase is associated with the changes that might have occurred in the protein of phenolic compounds, causing their exposure and the consequent increased availability (Lemos et al., 2012). Thermal processing is responsible for increasing the phenolic content due to the increase in the number of free phenolic groups resulting from the hydrolysis of glycosylated flavonoids that are released from the phenolic cell walls (D'archivio et al., 2010). Rodríguez-Bencomo et al., (2015), when studying the effects of the roasting process $\left(160^{\circ} \mathrm{C}\right.$ for $\left.20 \mathrm{~min}\right)$ in pistachios, found an increase of 17,79 and $81 \%$ in the presence of chlorogenic acid, rutin and catechin. It was also found that the drying (when comparing T1 to T3) promoted a reduction $(p<0.05)$ in the presence of chlorogenic acid, caffeic, $p$-coumaric acid, quercetin, ferulic and $o$-coumaric acid of 7.2, $41.3,30.2,9.4,74.3$ and $7.57 \%$, respectively. The decreases in these substances can be attributed to the effects of heat, which may have caused possible protein denaturation resulting from the disruption of covalent links (Shahidi and Yeo, 2016). 
Effects of the drying process on baru almonds $\bullet 7$

TABLE 2. Identification and quantification via HPLC-DAD/UV-Vis of phenolic compounds present in baru almonds submitted to different drying processes ${ }^{1}$

\begin{tabular}{|c|c|c|c|c|c|}
\hline \multirow[b]{2}{*}{ Phenolic Compound } & \multirow[b]{2}{*}{ Chemical Structure } & \multicolumn{4}{|c|}{ Treatments $\left(\mathrm{mg} \cdot 100 \mathrm{~g}^{-1}\right)^{2}$} \\
\hline & & T1 & T2 & T3 & $\mathbf{P}$ \\
\hline Gallic Acid & & $45.83 \pm 0.69^{\mathrm{c}}$ & $47.18 \pm 1.16^{\mathrm{b}}$ & $48.90 \pm 1.28^{\mathrm{a}}$ & 0.0001 \\
\hline Catechin & & $9.01 \pm 1.40^{\mathrm{c}}$ & $9.98 \pm 0.52^{\mathrm{b}}$ & $11.06 \pm 0.57^{\mathrm{a}}$ & 0.0001 \\
\hline Chlorogenic Acid & & $7.33 \pm 0.87^{\mathrm{a}}$ & $7.23 \pm 0.62^{\mathrm{b}}$ & $6.80 \pm 0.98^{\mathrm{c}}$ & 0.0001 \\
\hline Caffeic Acid & & $19.89 \pm 1.17^{\mathrm{a}}$ & $11.94 \pm 1.09^{\mathrm{b}}$ & $11.68 \pm 1.62^{\mathrm{c}}$ & 0.0001 \\
\hline Vanillin & & $7.56 \pm 0.01^{\mathrm{c}}$ & $9.18 \pm 0.33^{b}$ & $10.17 \pm 0.50^{\mathrm{a}}$ & 0.0001 \\
\hline$P$-coumaric & & $0.43 \pm 0.23^{\mathrm{a}}$ & $0.32 \pm 0.22^{\mathrm{b}}$ & $0.30 \pm 0.02^{\mathrm{c}}$ & 0.0001 \\
\hline Ferulic Acid & & $1.17 \pm 0.62^{\mathrm{a}}$ & $0.98 \pm 0.31^{\mathrm{b}}$ & $0.30 \pm 0.02^{\mathrm{c}}$ & 0.0001 \\
\hline$M$-coumaric & & $0.86 \pm 1.09^{\mathrm{c}}$ & $0.93 \pm 1.22^{\mathrm{b}}$ & $1.01 \pm 1.35^{\mathrm{a}}$ & 0.0002 \\
\hline$O$-coumaric & & $9.24 \pm 2.01^{\mathrm{a}}$ & $8.78 \pm 0.98^{b}$ & $8.54 \pm 0.20^{\mathrm{c}}$ & 0.0001 \\
\hline Quercetin & & $1.60 \pm 0.25^{\mathrm{a}}$ & $1.48 \pm 0.19^{\mathrm{b}}$ & $1.45 \pm 0.22^{\mathrm{b}}$ & 0.0002 \\
\hline Trans-Cinnamic Acid & & $9.12 \pm 0.27^{\mathrm{c}}$ & $9.41 \pm 1.44^{\mathrm{b}}$ & $10.12 \pm 1.70^{\mathrm{a}}$ & 0.0001 \\
\hline Rutin & & $17.81 \pm 1.40^{\mathrm{c}}$ & $17.89 \pm 1.04^{\mathrm{b}}$ & $18.40 \pm 0.74^{\mathrm{a}}$ & 0.0001 \\
\hline
\end{tabular}

${ }^{1}$ Mean values \pm standard deviation (in quadruple, $\mathrm{n}=4$ ). Values followed by different letters in the same line show differences by Tukey's test at $95 \%$ significance ( $<<0.05$ ); ${ }^{2}$ Treatments: T1 (Almond "in natura"), T2 (Almond submitted to $65^{\circ} \mathrm{C}$ for 30 minutes) and $\mathrm{T} 3$ (Almond submitted to $105^{\circ} \mathrm{C}$ per 30 minutes); $p$ : $p$-value. 
TABLE 3. Average of total sterols and tocopherols present in the baru almond submitted to different drying processes ${ }^{1}$

\begin{tabular}{lrrrr}
\hline & \multicolumn{4}{c}{ Treatments $^{2}$} \\
\cline { 2 - 5 } Analytical Determinations & \multicolumn{1}{c}{ T1 } & \multicolumn{1}{c}{ T2 } & P \\
\hline Total sterols $\left(\mathrm{mg} \cdot 100 \mathrm{~g}^{-1}\right)$ & $427.34 \pm 14.27$ & $432.76 \pm 13.59$ & $439.94 \pm 24.68$ & 0.7227 \\
$\alpha$ - tocopherol $\left(\mathrm{mg} \cdot \mathrm{kg}^{-1}\right)$ & $0.50 \pm 0.02^{\mathrm{c}}$ & $0.82 \pm 0.23^{\mathrm{b}}$ & $0.94 \pm 0.04^{\mathrm{a}}$ & 0.0001 \\
$\gamma$ - tocopherol $\left(\mathrm{mg} \cdot \mathrm{kg}^{-1}\right)$ & $1.47 \pm 0.32^{\mathrm{b}}$ & $1.33 \pm 0.02^{\mathrm{b}}$ & $2.33 \pm 1.75^{\mathrm{a}}$ & 0.0025 \\
$\sum \alpha+\gamma$ tocopherol $\left(\mathrm{mg} \cdot \mathrm{kg}^{-1}\right)$ & $1.97 \pm 0.23^{\mathrm{c}}$ & $2.15 \pm 0.35^{\mathrm{b}}$ & $3.27 \pm 0.10^{\mathrm{a}}$ & 0.0001 \\
\hline
\end{tabular}

${ }^{1}$ Mean values \pm standard deviation (in quadruple, $\mathrm{n}=4$ ). Values followed by different letters in the same line show differences by Tukey's test at $95 \%$ significance $(\mathrm{p}<0.05) ;{ }^{2}$ Treatments: T1 (Almond "in natura"), T2 (Almond submitted to $65{ }^{\circ} \mathrm{C}$ per 30 minutes) and T3 (Almond submitted to $105^{\circ} \mathrm{C}$ per 30 minutes); $\mathrm{p}$ : $p$-value.

\subsection{Determination of total sterols, tocopherols and fatty acids}

Total sterols. The determination of the total sterol contents of baru almonds subjected to different drying processes of drying is shown in Table 3.

The total sterol content of baru almonds was measured at an average of $432.66 \mathrm{mg} \cdot 100 \mathrm{~g}^{-1}$ without statistical difference $(p>0.05)$ among the treatments, and these results may demonstrate that the drying process does not influence these molecules. For health benefits, it is recommended to eat between 1 to $2 \mathrm{~g}$ of plant sterols a day. In this regard, the ingestion of $100 \mathrm{~g}$ of baru almonds can meet more than $40 \%$ of this recommendation (considering the consumption of $1 \mathrm{~g} /$ day). This result is favorable since these components have different physiological effects mainly in the treatment of hypercholesterolemia, as well as in the control of cholesterol by secondary causes in diabetics and patients with metabolic syndrome (Lemos et al., 2016). In addition, baru almonds present total sterol values greater than other oilseeds considering that Brazil's almonds, walnuts, cashews, hazelnuts, macadamia nuts, pistachios and walnuts have average total sterols of $192,160,154,132,105,189$ and $197 \mathrm{mg} \cdot 100$ $\mathrm{g}^{-1,}$ respectively (Miraliakbari and Shahidi, 2008).

Identification of tocopherols by HPLC-DAD. The total contents of tocopherols ( $\alpha$ and $\gamma)$ (Table 3) obtained among the treatments showed significant differences $(p<0.05)$ indicating that the drying process $\left(65\right.$ and $105^{\circ} \mathrm{C}$ for $30 \mathrm{~min}$ ) can contribute to an increase of 8.12 and $63.95 \%$ in these compounds, respectively. When evaluated individually, the tocopherols also presented the same behavior, and these data indicate that these substances may be enhanced through the use of heat. $\gamma$-tocopherol was the most abundant, with corresponding values for $\mathrm{T} 1, \mathrm{~T} 2$ and $\mathrm{T} 3$ of 74.6, 71.2 and $61.9 \%$, respectively of total tocopherol content. $\alpha$-tocopherol presented values of 25.3, 38.1 and $43.7 \%$ for the same treatments. Factors such as the composition in fatty acids, the presence of compounds with antioxidant activity (especially those from lipophilic), variety, degree of ripeness and care in almond production can be responsible for the maintenance of these molecules (Lemos et al., 2016). The quantification of the levels of tocopherols, specifically in food, becomes necessary due to the action of this vitamin in preventing oxidative damage to DNA, which act as antioxidant structures and assist in peroxidation inhibition of lipids (Lemos et al., 2016).

Profile of fatty acids by CG-FID. Table 4 presents the identification, quantification and relations among the saturated, polyunsaturated and unsaturated fatty acids present in baru almond subjected to different drying temperatures, as well as the atherogenic index (AI) and thrombogenic index (TI), and the hypocholesterolemic and hypercholesterolemic fatty acids $(\mathrm{h} / \mathrm{H})$.

It was found that the unsaturated fatty acids, including oleic and linoleic, were predominant. The high proportion of monounsaturated fatty acids and polyunsaturated was also observed. The Dietary Guidelines for Americans (AHA, 2016) states that the daily intake of PUFAs is $20 \mathrm{~g} \mathrm{~g}^{-1}$ and, in this sense, it is recommended to ingest $63.5,65.1$ and $64.1 \mathrm{~g}^{-1}$ baru almonds corresponding to $\mathrm{T} 1, \mathrm{~T} 2$ and $\mathrm{T} 3$ to provide $100 \%$ of this recommendation.

Among the saturated fatty acids, palmitic acid was the major representative in all treatments. The relation between PUFA/SFA was higher than 1.9, 1.8 and 1.8 respectively for $\mathrm{T} 1, \mathrm{~T} 2$ and $\mathrm{T} 3$, and $\mathrm{T} 2$ and T3 are statistically similar $(p<0.05)$. For a balanced intake of these elements, this value must be at least 0.45 . In relation to this profile (low levels of SFA and high of PUFAs), it is estimated that baru almonds can be effective in the control of the traditional risk factors for atherosclerotic cardiovascular disease. This is because the presence of polyunsaturated fatty acids may promote a hypocholesterolemic effect.

As to the atherogenic index (AI) and thrombogenic index (TI) and the hypocholesterolemic fatty acids and hypercholesterolemic $(\mathrm{h} / \mathrm{H})$, which indicate the potential for stimulating the aggregation platelet and coronary artery disease, the values obtained for T1, T2 and T3 were respectively 0.28 , $0.09,11.31,0.29,0.08,12.01$, and $0.27,0.07,12.58$ 
TABLE 4. Fatty acid profile of baru almonds submitted to different drying temperatures ${ }^{1}$

\begin{tabular}{|c|c|c|c|c|c|}
\hline \multirow[b]{2}{*}{ Fatty Acids $\left(g \cdot 100 g^{-1}\right)$} & \multicolumn{5}{|c|}{ Treatments $^{2}$} \\
\hline & Chemical Structure & T1 & T2 & T3 & $\mathbf{P}$ \\
\hline Methyl Hexanoate & C6:0 & $0.03 \pm 0.00^{\mathrm{a}}$ & $0.03 \pm 0.00^{\mathrm{a}}$ & $0.01 \pm 0.01^{\mathrm{b}}$ & 0.0271 \\
\hline Methyl Octanoate & C8:0 & $0.03 \pm 0.00^{\mathrm{b}}$ & $0.03 \pm 0.00^{\mathrm{b}}$ & $0.06 \pm 0.17^{\mathrm{a}}$ & 0.0001 \\
\hline Methyl Decanoate & $\mathrm{C} 10: 0$ & $0.03 \pm 0.02^{\mathrm{a}}$ & $0.02 \pm 0.07^{\mathrm{a}}$ & $0.00 \pm 0.09^{\mathrm{b}}$ & 0.0001 \\
\hline Methyl Laurate & $\mathrm{C} 12: 0$ & $0.24 \pm 0.06^{\mathrm{a}}$ & $0.13 \pm 0.01^{\mathrm{b}}$ & $0.08 \pm 0.06^{\mathrm{c}}$ & 0.0001 \\
\hline Methyl Myristate & $\mathrm{C} 14: 0$ & $0.16 \pm 0.03^{\mathrm{a}}$ & $0.11 \pm 0.23^{\mathrm{b}}$ & $0.05 \pm 0.02^{\mathrm{c}}$ & 0.0001 \\
\hline Methyl Pentadecanoate & $\mathrm{C} 15: 0$ & $0.22 \pm 0.03^{\mathrm{a}}$ & $0.18 \pm 0.21^{\mathrm{b}}$ & $0.18 \pm 0.06^{\mathrm{b}}$ & 0.0001 \\
\hline Methyl Palmitate & $\mathrm{C} 16: 0$ & $6.59 \pm 0.04^{\mathrm{a}}$ & $6.28 \pm 0.03^{\mathrm{b}}$ & $6.16 \pm 0.01^{\mathrm{c}}$ & 0.0001 \\
\hline Methyl Heptadecanoate & $\mathrm{C} 17: 0$ & $0.09 \pm 0.03^{\mathrm{a}}$ & $0.08 \pm 0.13^{\mathrm{b}}$ & $0.08 \pm 0.01^{\mathrm{b}}$ & 0.0076 \\
\hline Methyl Stearate & $\mathrm{C} 18: 0$ & $4.39 \pm 0.21^{\mathrm{a}}$ & $5.32 \pm 0.08^{\mathrm{a}}$ & $5.22 \pm 0.12^{\mathrm{b}}$ & 0.0001 \\
\hline Methyl Arachidate & $\mathrm{C} 20: 0$ & $1.06 \pm 0.07^{\mathrm{c}}$ & $1.18 \pm 0.09^{\mathrm{b}}$ & $1.21 \pm 0.16^{\mathrm{a}}$ & 0.0001 \\
\hline Methyl Behenate & $22: 00$ & $3.47 \pm 0.25^{\mathrm{c}}$ & $3.67 \pm 0.54^{\mathrm{b}}$ & $3.73 \pm 0.43^{\mathrm{c}}$ & 0.0001 \\
\hline$\sum \mathrm{SFA}^{3}$ & - & $16.32 \pm 0.71^{\mathrm{c}}$ & $17.04 \pm 0.53^{\mathrm{a}}$ & $16.79 \pm 0.65^{\mathrm{b}}$ & 0.0001 \\
\hline Cis-10-pentadecanoic acid methyl ester & $\mathrm{C} 15: 1$ & $0.031 \pm 0.01^{\mathrm{a}}$ & $0.07 \pm 0.03^{\mathrm{b}}$ & $0.02 \pm 0.01^{\mathrm{b}}$ & 0.0041 \\
\hline Methyl Palmitoleate & $\mathrm{C} 16: 1$ & $0.08 . \pm 0.01^{\mathrm{a}}$ & $0.07 \pm 0.01^{\mathrm{b}}$ & $0.07 \pm 0.02^{\mathrm{b}}$ & 0.0012 \\
\hline Cis-10-heptadecanoic acid methyl ester & $\mathrm{C} 17: 1$ & $0.15 \pm 0.02^{\mathrm{a}}$ & $0.13 \pm 0.76^{\mathrm{b}}$ & $0.13 \pm 0.16^{\mathrm{c}}$ & 0.0001 \\
\hline Cis-9-oleic acid methyl ester & $\mathrm{C} 18: 1 \Omega 9$ & $48.99 \pm 0.07^{\mathrm{c}}$ & $50.15 \pm 1,98^{\mathrm{b}}$ & $51.01 \pm 0.62^{\mathrm{a}}$ & 0.0001 \\
\hline Methyl cis-11-Eicosenoate & $\mathrm{C} 20: 1$ & $2.40 \pm 0.87^{\mathrm{c}}$ & $2.52 \pm 0.54^{\mathrm{b}}$ & $2.56 \pm 0.19^{\mathrm{a}}$ & 0.0001 \\
\hline Methyl Erucate & $22: 1 \Omega 9$ & $0.26 \pm 0.06^{\mathrm{c}}$ & $0.28 \pm 0.01^{\mathrm{b}}$ & $0.29 \pm 0.05^{\mathrm{a}}$ & 0.0001 \\
\hline$\sum$ MUFA $^{4}$ & - & $51.91 \pm 1.98^{\mathrm{c}}$ & $53.18 \pm 1.34^{\mathrm{b}}$ & $54.08 \pm 1.54^{\mathrm{a}}$ & 0.0001 \\
\hline Methyl Linoleate & $\mathrm{C} 18: 2 \Omega 6$ & $27.28 \pm 0.23^{\mathrm{c}}$ & $26.46 \pm 0.35^{\mathrm{b}}$ & $26.89 \pm 0.04^{\mathrm{a}}$ & 0.0001 \\
\hline Methyl Linolenate & $\mathrm{C} 18: 3 \Omega 3$ & $0.14 \pm 0.01^{\mathrm{a}}$ & $0.13 \pm 0.03^{\mathrm{b}}$ & $0.12 \pm 0.05^{\mathrm{c}}$ & 0.0001 \\
\hline Cis-11,14-eicosadienoic acid methyl ester & $\mathrm{C} 20: 2 \Omega 6$ & $0.08 \pm 0.05^{\mathrm{a}}$ & $0.06 \pm 0.07^{\mathrm{b}}$ & $0.05 \pm 0.22^{\mathrm{c}}$ & 0.0001 \\
\hline Methyl cis-5,8,11,14,17-eicosapentaenoate & $\mathrm{C} 20: 5 \Omega 3$ & $0.07 \pm 0.09^{\mathrm{a}}$ & $0.06 \pm 0.06^{\mathrm{b}}$ & $0.05 \pm 0.32^{\mathrm{c}}$ & 0.0004 \\
\hline Cis-13,16-docasadienoic acid methyl ester & $\mathrm{C} 22: 2$ & $3.93 \pm 0.35^{\mathrm{c}}$ & $4.04 \pm 1.78^{\mathrm{b}}$ & $4.13 \pm 0.97^{\mathrm{a}}$ & 0.0001 \\
\hline$\sum$ PUFA $^{5}$ & - & $31.50 \pm 1.04^{\mathrm{a}}$ & $30.74 \pm 0.75^{\mathrm{c}}$ & $31.25 \pm 0.69^{\mathrm{b}}$ & 0.0001 \\
\hline PUFA/SFA ${ }^{6}$ & - & $1.93 \pm 0.14^{\mathrm{a}}$ & $1.80 \pm 0.45^{\mathrm{b}}$ & $1.82 \pm 0.76^{\mathrm{b}}$ & 0.0001 \\
\hline MUFA/SFA ${ }^{7}$ & - & $3.180 \pm 0.53^{\mathrm{a}}$ & $3.12 \pm 0.25^{\mathrm{b}}$ & $1.87 \pm 0.34^{\mathrm{c}}$ & 0.0001 \\
\hline $\mathrm{TI}^{8}$ & - & $0.28 \pm 0.21^{\mathrm{b}}$ & $0.29 \pm 0.08^{\mathrm{a}}$ & $0.28 \pm 0.21^{\mathrm{b}}$ & 0.0003 \\
\hline $\mathrm{AI}^{9}$ & - & $0.09 \pm 0.09^{\mathrm{a}}$ & $0.08 \pm 0.76^{\mathrm{b}}$ & $0.08 \pm 0.34^{\mathrm{c}}$ & 0.0001 \\
\hline $\mathrm{h} / \mathrm{H}^{10}$ & - & $11.32 \pm 0.24^{\mathrm{c}}$ & $12.02 \pm 1.12^{\mathrm{b}}$ & $12.59 \pm 0.43^{\mathrm{a}}$ & 0.0001 \\
\hline
\end{tabular}

${ }^{1}$ Mean values \pm standard deviation (in quadruple, $\mathrm{n}=4$ ). Values followed by different letters in the same line show differences by Tukey's test at $95 \%$ significance ( $<<0.05$ ); ${ }^{2}$ Treatments: T1 (Almond "in natura"), T2 (Almond submitted to $65^{\circ} \mathrm{C}$ for 30 minutes) and T3 (Almond submitted to $105^{\circ} \mathrm{C}$ for 30 minutes); ${ }^{3}$ Total saturated fatty acids; ${ }^{4}$ Total unsaturated fatty acids; ${ }^{5}$ Total of polyunsaturated fatty acids; ${ }^{6}$ Relationship between saturated and polyunsaturated fatty acids; ${ }^{7}$ Relationship between saturated and unsaturated fatty acids $;{ }^{8}$ Thrombogenic index; ${ }^{9}$ Atherogenic index; ${ }^{10}$ hypocholestrolemic/ hypercholesterolemic potential; $p: p$-value

with statistical difference $(p<0.05)$ among the treatments. Although there is no established parameter for these indices, the smaller the result for AI and TI and greater for $\mathrm{h} / \mathrm{H}$, the less likely are the changes as mentioned above and the healthier the food is. This is due to the greater concentration of anti-atherogenic fatty acids $(\Omega 3$ and $\Omega 6$ ) (Turan et al., 2007). Foods such as cheeses and meats that are significant sources of fatty acids, have indexes of AI, TI and respective $\mathrm{h} / \mathrm{h} 2.32,3.11,1.23$ and $0.54,1.15,1.76$ (Faria et al., 2015), and comparing these figures with those of baru almonds, the superiority and greater possibility of cardiovascular protection on the part of the almond is demonstrated.

With regards to the drying process (T3), it was found that heat promoted a reduction $(p<0.05)$ in different fatty acids (relative to T1) in C16:0 and C18:2 of 1.4 and $6.6 \%$. By analyzing all the reductions and correlating them to the degree of unsaturation, one can infer that polyunsaturated fatty acids were the most affected. This may be due to the fact that this compound has a greater number of double bonds, which results in increased susceptibility to oxidation. 
Conversely, this same process of drying promoted increases $(p<0.05)$ in different fatty acids, C18:0, C18:1, C22:0 and C22:2 with expansion of $18.9,4.1,4.9$ and $7.5 \%$, respectively. The saturated fatty acids were the most favored by the drying process (when compared to T1 with T3), because they represented together a total increase of $134.6 \%$. This occurs because heating may increase the oxidation rate of these molecules. Rodríguez-Bencomo et al., (2015), when analyzing pistachio oil subjected to heating $\left(160^{\circ} \mathrm{C}\right.$ for $\left.20 \mathrm{~min}\right)$, found that heat is not promoted and there is no significant increase in the levels of SFA, PUFA and MUFA.

\section{CONCLUSIONS}

High levels of phenolic compounds, vitamin C, antioxidants (measured by the $\beta$-carotene/linoleic acid systems), gallic acid, caffeic acid, rutin, sterols, total monounsaturated fatty acids and low thrombogenic, atherogenic index were found in "in natura" baru almonds. During the process of drying at $65^{\circ} \mathrm{C}$ for $30 \mathrm{~min}$, a decline in the levels of caffeic, chlorogenic acid, anthocyanins, $p$-coumaric acid, ferulic, $o$-coumaric acid, quercetin, polyunsaturated fatty acids and the free radical scavenging capacity was observed. Under the same conditions, an increase in the levels of gallic acid, rutin, catechin, trans-cinnamic acid, vanillin, $m$-coumaric acid, tocopherols and monounsaturated fatty acids was observed. The temperature of $105^{\circ} \mathrm{C}$ presented the same behavior as above, however, it caused a reduction in vitamin $\mathrm{C}$ content and the increase in the presence of flavonoids. The drying temperature did not affect the levels of total phenolics, tannins, $\beta$ - carotene/linoleic acid system, or sterols. The chromatographic and spectrophotometric quantifications carried out in this work contributed to an increase in the scientific knowledge about the properties of baru almonds submitted to different drying processes in relation to the work already done and published in the scientific community. The almonds of this study present functional features that place it above other oilseeds. Its consumption promotes the plant biodiversity of the Cerrado Biome and contributes to a new generation of foods that can benefit the health of consumers. The bioactive properties of the molecules that are intensified by processing suggest great potential for application of baru almonds ("in natura" and/ or submitted to different drying processes) in new products such as oils, cereal bars, bakery, chocolate, among others. However, their application depends on the adequacy of the industrial scale.

\section{ACKNOWLEDGMENTS}

We recognize and appreciate the Council for Scientific and Technological Development (CNPq) for granting the scholarship, to the Minas
Gerais Research Foundation (FAPEMIG) for the financial resources for project execution (CAG Process - APQ-00798-16) and to Coordination of Improvement of Higher Education (CAPES) for their help in the execution of this research.

\section{REFERENCES}

Aazza S, Lyoussi B, Miguel MG. 2011. Antioxidant activity of some Morrocan hydrosols. J. Med. Plants Res. 5, 6688-6696.

American Heart Association Guidelines online [Internet]. c2015 - 2016. CPR \& ECC: AHA; [cited 2016 Nov 16].

AOAC. 1990. Official methods of analysis of AOAC international, 15th ed. Washington, DC, USA: Association of Official Analytical Chemists. p. 1990.

D'archivio M, Filesi C, Varì R, Scazzocchio B, Masella R. 2010. Bioavailability of the Polyphenols: Status and Controversies. Int. J. Mol. Sci. 11, 1321-1342. https://doi. org/10.3390/ijms11041321

Faria PB, Cantarelli VS, Filho ET, Pinto AMBG, Faria JH, Rocha MFM, Bressan MC. 2015. Lipid profile and cholesterol of pork with the use of glycerin in feeding. Arq. Bras. Med. Vet. Zootec. 67, 535-546.

Fatin NR, Azrina A. 2017. Comparison of vitamin C content in citrus fruits by titration and high performance liquid chromatography (HPLC) methods. Int. Food Res. 24, 726-733.

Folch J, Lees M, Stanley SA. 1957. A simple method for isolation and purification of total lipids from animal tissues. J. Biol. Chem. 226, 479-503.

Fraguas RM, Simão AA, Leal RS, Santos CM, Rocha DA, Tavares TS, Abreu CMP. 2014. Chemical composition of processed baru (Dipteryx alata Vog.) almonds: Lyophilization and roasting. Afr. J. Agric. Res. 9, 10611069. https://doi.org/10.5897/AJAR2014.8469

Freitas LS, Jacques RA, Richter MF, Silva AL, Caramão EB. 2008. Pressurized liquid extraction of vitamin $\mathrm{E}$ from Brazilian grape seed oil. J. Chromatogr. A 1200, 80-83. https://doi.org/10.1016/j.chroma.2008.02.067

Giusti MM, Wrolstad RE. 2001. Characterization and Measurement of Anthocyanins by UV-Visible Spectroscopy. Current Protocols in Food Analytical Chemistry. Vol. 0 (1) F1.2.1-13. https://doi.org/10.1002/0471142913.faf0102s00

Guimarães EL, Franceschi MF, Andrade C, Guaragna RM, Borojevic R, Margis R. 2007. Hepatic stellate cell line modulates lipogenic transcription factors. Liver Int. 27, 1255-64. https://doi.org/10.1111/j.1478-3231.2007.01578.x

Igual M, García-Martínez E, Martín-Esparza N, MartínezNavarrete N. 2012. Effect of processing on the drying kinetics and functional value of dried apricot. Food Res. Int. 47, 284-290. https://doi.org/10.1016/j.foodres.2011.07.019

Kenny AP. 1952. The determination of cholesterol by the Liebermann-Burchard reaction. Biochem. J. 52, 611-619. https://doi.org/10.1042/bj0520611

Kornsteiner M, Karl-Heinz W, Elmadfa I. 2006. Tocopherols and total phenolics in 10 different nut types. Food Chem. 98, 381-387. https://doi.org/10.1016/j.foodchem.2005.07.033

Lemos MRB, Siqueira EM, Arruda SF, Zambiazi RC. 2012. The effect of roasting on the phenolic compounds and antioxidant potential of baru nuts (Dipteryx alata Vog.). Food Res. Int. 48, 592-597. https://doi.org/10.1016/j.foodres.2012.05.027

Lemos MRB, Zambiazi RC, de Almeida EM, de Alencar ER. 2016. Tocopherols and Fatty Acid Profile in Baru Nuts (Dipteryx Alata Vog.), Raw and Roasted: Important Sources in Nature that Can Prevent Diseases. Food Sci. Nutr. Technol. 1, 1-11.

Liu G, Guasch-Ferre M, Hu Y, Li Y, Hu FB, Rimm EB, Manson JE, Rexrode K, Sun Q. 2019. Nut Consumption in Relation to Cardiovascular Disease Incidence and Mortality among Patients with Diabetes Mellitus. Circ. Res. 19, 1-18. https:// doi.org/10.1161/CIRCRESAHA.118.314316

Liu Y, Kitts D. 2011. Confirmation that the Maillard reaction is the principle contributor to the antioxidant capacity of coffee brews. Food Res. Int. 44, 2418-2424. https://doi. org/10.1016/j.foodres.2010.12.037 
Macáková K, Koleckár V, Cahlíková L, Chlebeck J, Hostálková A, Kuca K. Opletal L. 2014. Tannins and their Influence on Health. Rec. Adv. Med. Chem. 1, 159-208. https://doi. org/10.1016/B978-0-12-803961-8.50006-3

Milardovic S, Ivekovic D, Grabaric BS. 2006. A novel amperometric method for antioxidant activity determination using DPPH free radical. Bioelectrochem. 68, 175-180. https:// doi.org/10.1016/j.bioelechem.2005.06.005

Miller HE. 1971. A simplified method for the evaluation of antioxidant. J. Am. Oil Chem. Soc. 48, 91-97. https://doi. org/10.1007/BF02635693

Miraliakbari H, Shahidi F. 2008. Oxidative stability of tree nut oils. J. Agric. Food Chem. 56, 4751-4759. https://doi. org/10.1021/jf8000982

Naczk M, Shahidi F.2004. Extraction and analysis of phenolics in food. J. Chromatogr. A 1054, 95-111. https://doi. org/10.1016/S0021-9673(04)01409-8

Palombini SV, Claus T, Maruyama SA, Carbonera F, Montanher PF, Visentainer JV, Matsushita M. 2016. Optimization of a New Methodology for Determination of Total Phenolic Content in Rice Employing Fast Blue $\mathrm{BB}$ and QUENCHER Procedure. J. Braz. Chem. Soc.7, 1188-1194. https://doi.org/10.5935/0103-5053.20160013

Pasqualone A, Laddomada B, Spina $\mathrm{A}$, Todaro $\mathrm{A}$, Guzmàn C, Summo C, Mita G, Giannone V. 2018. Almond byproducts: Extraction and characterization of phenolic compounds and evaluation of their potential use in composite dough with wheat flour. $L W T \mathbf{8 9}, 299-306$. https:// doi.org/10.1016/j.lwt.2017.10.066

Ramaiya SD, Bujang JS, Zakaria MH, Kinga WS, Sahrira MAS. 2013. Sugars, ascorbic acid, total phenolic content and total antioxidant activity in passion fruit (Passiflora) cultivars. J. Sci. Food Agric. 93, 1198-1205. https://doi. org/10.1002/jsfa. 5876

Rodríguez-Bencomo JJ, Kelebek H, Soezdag AS, RodríguezAlcalá LM, Fontecha J, Selli S. 2015. Characterization of the aroma-active, phenolic, and lipid profiles of the pistachio (Pistacia vera L.) nut as affected by the single and double roasting process. J. Agric. Food Chem. 63, 7830-7839. https://doi.org/10.1021/acs.jafc. $5 \mathrm{~b} 02576$

Santos-Silva J, Bessa RJB, Santos-Silva F. 2002. Effects of genotype, feeding system and slaughter weigt on the quality of light lambs. Fatty acid composition of meat. Livest. Prod. Sci. 77, 187-194. https://doi.org/10.1016/ S0301-6226(01)00334-7

Shahidi F, Yeo J. 2016. Insoluble-Bound Phenolics in Food. Molecules 21, 1-22. https://doi.org/10.3390/molecules 21091216

Ulbricht TLV, Southgate DAT. 1991. Coronary Heart Disease: Seven Dietary Factors. Lancet 338, 985-992. https://doi. org/10.1016/0140-6736(91)91846-M 